\title{
Infeksi Susunan Saraf Pusat pada Anak: Sebuah Studi Potong Lintang Deskriptif Selama Lima Tahun
}

Gilbert Sterling Octavius, ${ }^{1}$ Albertus Boyke Raditya, ${ }^{1}$ Ervina Kimberly, ${ }^{1}$ Jeremiah Suwandi, ${ }^{1}$ Monica Christy, ${ }^{1}$ Andry Juliansen ${ }^{2}$

${ }^{1}$ Fakultas Kedokteran Universitas Pelita Harapan, Karawaci, Tangerang, Banten

${ }^{2}$ Departemen Ilmu Kesehatan Anak Fakultas Kedokteran Universitas Pelita Harapan, Karawaci, Tangerang, Banten

Latar belakang. Infeksi susunan saraf pusast memiliki morbiditas dan mortalitas apabila tidak ditangani secara tepat. Penanganan yang tidak sesuai juga berisiko tinggi untuk menimbulkan kecacatan pada kemudian hari. Tipe-tipe infeksi susunan saraf pusat dapat berupa meningitis, ensefalitis dan meningoensefalitis yang memiliki etiologi dan manifestasi klinis yang beragam.

Tujuan. Penelitian ini bertujuan untuk mendeskripsikan karakteristik klinis pada setiap infeksi sistem saraf pusat baik dari segi manifestasi klinis, radiologis, serta terapi pada setiap pasien.

Metode. Anak berusia 0-18 tahun yang didiagnosis meningitis, ensefalitis dan meningoensefalitis dari Januari 2015 hingga September 2019 diinklusikan pada studi potong lintang ini. Data diambil melalui rekam medis.

Hasil. Terdapat 45 pasien yang memenuhi kriteria inklusi dan eksklusi dan laki-laki mendominasi pada studi ini (57,8\%). Meningitis ditemukan pada $37,8 \%$ pasien, ensefalitis pada $22,2 \%$ pasien, dan meningoensefalitis pada $40 \%$ pasien. Tuberkulosis menjadi etiologi tersering yang ditemukan pada studi ini sebesar 71,1\%. Median durasi rawat inap terpanjang ditemukan pada pasien dengan meningoensefalitis (15,5 hari) dan kortikosteroid merupakan pengobatan yang sering digunakan untuk mengatasi infeksi susunan saraf pusat.

Kesimpulan. Infeksi SSP lebih sering terjadi pada anak di bawah $<5$ tahun. Sebagian besar anak-anak datang dengan penurunan kesadaran akut dan TB masih merupakan penyebab utama dari infeksi SSP. Pasien dengan meningitis TB atau meningoensefalitis TB datang dengan derajat MRC 2-3 yang berkorelasi dengan morbiditas dan mortalitas tinggi sehingga diagnosis dan tatalaksana yang tepat diperlukan oleh para klinisi untuk memperbaiki luaran pasien. Sari Pediatri 2021;23(1):6-14

Kata kunci: infeksi susunan saraf pusat, anak, meningitis, ensefalitis, meningoensefalitis

\section{Central Nervous System Infections in Children: A Five-Year Descriptive Cross-Sectional Study}

Gilbert Sterling Octavius, ${ }^{1}$ Aboy Raditya, ${ }^{1}$ Ervina Kimberly, ${ }^{1}$ Jeremiah Suwandi, ${ }^{1}$ Monica Christy, ${ }^{1}$ Andry Juliansen ${ }^{2}$

Background. Central nervous infections have a high morbidity and mortality rate if not treated properly. Delayed treatments also have a high risk of causing disability in the future. The types of central nervous system infections can include meningitis, encephalitis and meningoencephalitis which have various etiologies and clinical manifestations.

Objective. This study aims to describe the clinical characteristics of each central nervous system infection in terms of clinical, radiological, and therapeutic manifestations in each patient.

Methods. Children aged 0-18 years who were diagnosed with meningitis, encephalitis and meningoencephalitis from January 2015 to September 2019 were included in this cross-sectional study. The data were collected through medical records and this research has received ethical approval from the Faculty of Medicine, University of Pelita Harapan.

Results. There were 45 patients who met the inclusion and exclusion criteria and male patients dominated this study (57.8\%). Meningitis was present in $37.8 \%$ of patients, encephalitis in $22.2 \%$ of patients, and meningoencephalitis in $40 \%$ of patients. Tuberculosis was the most common etiology found in this study at $71.1 \%$. The longest median duration of hospitalization was found in patients with meningoencephalitis (15.5 days) and corticosteroids are the most commonly used treatment for central nervous system infections.

Conclusion. Central nervous system infection is more common in children $<5$ years. Most of the children present with acute loss of consciousness and tuberculosis are still the main cause of CNS infection. Patients with TB meningitis or TB meningoencephalitis present with an MRC grade of 2-3 which is correlated with high morbidity and mortality so that proper diagnosis and management is required by clinicians to improve patient outcomes. Sari Pediatri 2021;23(1):6-14

Keywords: central nervous system infections, children, meningitis, encephalitis, meningoencephalitis

Alamat korespondensi: Gilbert Sterling Octavius. Fakultas Kedokteran Universitas Pelita Harapan, Karawaci, Tangerang, Banten. Email: sterlinggilbert613@hotmail.com 
Gilbert Sterling Octavius dkk: Infeksi susunan saraf pusat pada anak: sebuah studi potong lintang deskriptif selama lima tahun

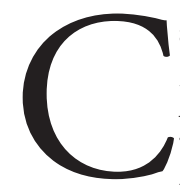

airan tubuh steril yang terinfeksi dapat mengakibatkan morbiditas dan mortalitas yang berat sehingga membutuhkan penanganan yang tepat sesuai dengan etiologi dari mikroorganisme tersebut. ${ }^{1}$ Infeksi pada meningens disebut meningitis, ${ }^{1}$ infeksi pada jaringan otak disebut ensefalitis ${ }^{2}$ dan apabila mengenai jaringan otak dan meningens maka disebut meningoensefalitis. ${ }^{3}$

Terdapat beberapa etiologi untuk meningitis seperti bakteri, virus atau jamur walaupun etiologi jamur lebih jarang ditemukan. ${ }^{4}$ Insiden meningitis bakterial diperkirakan 3-5 per 100.000 orang setiap tahunnya dan hampir setengah meninggal walaupun telah mendapat penanganan yang tepat. Neisseria meningitidis dan Streptococcus pneumoniae merupakan penyebab tersering meningitis bakterial. ${ }^{5}$ Haemophilus influenzae type $b$ (Hib) dulu merupakan salah satu penyebab tersering dari meningitis bakteri, tetapi vaksin konjugat untuk Hib merubah profil epidemiologi dari penyebab meningitis bakteri akibat Hib. ${ }^{6}$ Mortalitas meningitis bakteri diperkirakan 20-25\% walaupun terapi antimikrobial dan perawatan di ruang intensif semakin membaik. ${ }^{7}$ Di antara $10-20 \%$ pasien yang tidak meninggal akan menderita komplikasi permanen, ${ }^{6}$ seperti kehilangan pendengaran, disabilitas dalam belajar, kejang, rusaknya sel otak hingga kematian. ${ }^{8}$

Ensefalitis akut diasosiasikan dengan morbiditas dan mortalitas tinggi, 3,5 sampai 7,4 kasus dilaporkan per 100.000 orang setiap tahunnya. ${ }^{9}$ Virus dianggap sebagai etiologi terpenting dalam kasus akut ensefalitis, tetapi bakteri, parasit, toksin dan autoimun juga dianggap sebagai etiologi yang penting. ${ }^{10}$ Beberapa virus neurotropik berperan sebagai etiologi ensefalitis viral akut dan prevalensi tersering sangat tergantung pada letak geografis. ${ }^{11}$ Studi California Encephalitis Project menemukan bahwa virus herpes simpleks-1 (Herpes Simplex Virus 1 [HSV-1]) merupakan virus tersering yang menyebabkan ensefalitis, ${ }^{12}$ sedangkan negara di Asia Tenggara, seperti Kamboja dan Vietnam melaporkan bahwa Japanese Encephalitis virus (JEV) merupakan penyebab ensefalitis akut terbanyak dengan $31-45 \%$ pasien menderita ensefalitis akut akibat JEV. ${ }^{14}$

Virus merupakan penyebab tersering dari meningoensefalitis di seluruh dunia walaupun patogen lain dapat terlibat, seperti bakteri, parasit dan autoimun. ${ }^{15}$ Meningoensefalitis tuberkulosis (TB) disebabkan oleh Mycobacterium tuberculosis (M. tuberculosis) dan merupakan manifestasi tersering dari TB pada sistem saraf pusat yang diasosiasikan dengan sekuele neurologis dan mortalitas yang tinggi bila tidak ditangani dengan segera. ${ }^{16}$ Di Indonesia, $16 \%$ anak menderita TB pada tahun 2014 dan angka ini menempatkan Indonesia dalam 5 negara tertinggi dengan jumlah kasus TB terbanyak di dunia. ${ }^{17}$ Meningoensefalitis TB jarang ditemukan pada negara berkembang, 100 hingga 150 kasus terjadi setiap tahunnya di Amerika Serikat, ${ }^{16}$ sedangkan di Kosovo ditemukan 10 hingga 20 kasus per tahunnya. ${ }^{18}$

Pada penelitian ini kami melaporkan infeksi sistem saraf pusat (SSP) selama lima tahun terakhir serta mendeskripsikan karakteristik klinis pada setiap infeksi sistem saraf pusat.

\section{Metode}

Tujuan dari studi ini adalah untuk melihat angka prevalensi dari meningitis, ensefalitis, dan meningoensefalitis di Rumah Sakit Umum Siloam serta mendeskripsikan karateristik klinis dan luaran pada setiap pasien dengan infeksi sistem saraf pusat. Anak berusia 0-18 tahun yang didiagnosis meningitis, ensefalitis dan meningoensefalitis dari Januari 2015 hingga September 2019 diinklusikan pada studi potong lintang ini. Studi ini telah mendapatkan keterangan lolos kaji etik dengan nomor 136/K-LKJ/ETIK/V/2019.

Data demografis yang dimasukkan adalah jenis kelamin, usia saat masuk rumah sakit, status infeksi Human Immunodeficiency Virus (HIV), dokumentasi imunisasi Bacille Calmette Guerin (BCG), kontak TB dan etiologi dari setiap infeksi sistem saraf pusat.

Diagnosis definitif ditegakkan apabila ditemukan etiologi infeksi dari kultur cairan serebrospinal (LCS). Pada kasus lain, diagnosis dianggap sebagai probable berdasarkan gejala klinis dari setiap infeksi sistem saraf pusat dengan karakteristik LCS yang sesuai untuk setiap infeksi tersebut. Untuk probable meningitis tuberkulosis (MTB) atau meningoensefalitis tuberkulosis, diagnosis akan semakin ditegakkan apabila terdapat salah satu atau lebih dari kriteria berikut ini, (1) gizi kurang atau gizi buruk, (2) kontak dengan pasien TB dengan batang tahan asam (BTA) positif atau BTA negatif, (3) hasil computed tomography (CT) scan yang sesuai dengan MTB atau meningoensefalitis TB, (4) rontgen paru yang sesuai dengan TB primer, (5) tes tuberkulin positif dan (6) spesimen klinis lainnya yang positif untuk BTA. 
Peneliti mentabulasi stadium klinis penyakit, durasi gejala sebelum datang ke rumah sakit, keluhan utama, status nutrisi, skor Glasgow Coma Scale (GCS), fungsi motorik dan kelainan motorik lainnya. Untuk meningoensefalitis TB, stadium klinis diklasifikasikan berdasarkan kriteria British Medical Research Council yang telah dimofidikasi: stadium 1 apabila GCS 15 dan tidak ada kelainan neurologis fokal, stadium 2 apabila GCS 11-14 atau GCS 15 dengan defisit neurologis fokal dan stadium 3 apabila GCS $<11 .{ }^{19}$

Fungsi motoris diklasifikasikan sebagai normal, hemiparesis sinistra atau dekstra, kuadriparesis, monoparesis, paraparesis, ada tidaknya klonus atau spasme. Tanda neurologis lainnya yang diperhatikan adalah ada atau tidaknya iritasi meningeal, tanda peningkatan tekanan intrakranial (fontanel yang menonjol, mata sunset dan papiledema), disfungsi batang otak (pupil anisokor atau nonreaktif atau refleks okulosefalik negatif) dan palsi nervus kranialis.

Pada pemindaian CT dinilai adanya meningitis basalis, tuberkuloma, infark, hidrosefalus, empiema dan abses. Penemuan $x$-ray toraks yang sugestif untuk menunjang TB sebagai penyebab dari infeksi sistem saraf pusat adalah pembesaran kelenjar hilus atau paratrakeal dengan/tanpa infiltrat, konsolidasi segmental/lobar, efusi pleura, milier, atelektasis, kavitas, kalsifikasi dengan infiltrat dan tuberkuloma.

Isolasi etiologi dari LCS menegakkan diagnosis definitif untuk setiap infeksi sistem saraf pusat. Isolasi $M$. tuberculosis dari bilasan lambung, aspirasi bronkial, sputum atau kelenjar getah bening dikombinasikan dengan tanda klinis meningitis atau meningoensefalitis TB menambah nilai klinis dari infeksi tersebut.

Tes tuberkulin atau Mantoux dianggap positif sesuai dengan kriteria World Health Organization (WHO), yaitu indurasi $\geq 5 \mathrm{~mm}$ pada anak dengan risiko tinggi (anak dengan HIV atau gizi buruk) dan indurasi $\geq 10$ mm pada anak-anak lainnya. ${ }^{20}$

\section{Hasil}

Dari 116 pasien yang dicurigai menderita infeksi sistem saraf pusat (SSP), terdapat 45 pasien anak yang memenuhi kriteria meningitis, ensefalitis, atau meningoensefalitis untuk penelitian ini. Tujuhpuluh satu data tidak memiliki data yang lengkap pada rekam medis atau tidak terbukti menderita infeksi SSP sehingga masuk pada kriteria eksklusi. Data demografis

Tabel 1. Data demografis

\begin{tabular}{|c|c|c|c|c|c|}
\hline \multirow[t]{2}{*}{ Variabel } & & \multicolumn{2}{|c|}{ Meningitis } & \multirow[t]{2}{*}{ Ensefalitis (\%) } & \multirow[t]{2}{*}{ Meningoensefalitis (\%) } \\
\hline & & Bakterial (\%) & TB (\%) & & \\
\hline \multirow[t]{2}{*}{ Jenis kelamin } & Laki-laki & $3(100)$ & $10(71,4)$ & $3(30)$ & $10(55,6)$ \\
\hline & Perempuan & $0(0)$ & $4(28,6)$ & $7(70)$ & $8(44,4)$ \\
\hline \multirow{4}{*}{$\begin{array}{l}\text { Usia saat masuk rumah } \\
\text { sakit (tahun) }\end{array}$} & $0-1$ & $0(0)$ & $0(0)$ & $3(30)$ & $3(16,7)$ \\
\hline & $1-2$ & $1(33,3)$ & $3(21,4)$ & $3(30)$ & $2(11,1)$ \\
\hline & $2-5$ & $1(33,3)$ & $5(35,7)$ & $0(0)$ & $4(22,2)$ \\
\hline & $>5$ & $1(33,3)$ & $6(42,9)$ & $4(40)$ & $9(50)$ \\
\hline \multirow[t]{3}{*}{ Infeksi HIV } & Positif & $0(0)$ & $0(0)$ & $0(0)$ & $0(0)$ \\
\hline & Negatif & $3(100)$ & $11(78,6)$ & $0(0)$ & $4(22,2)$ \\
\hline & Tidak diketahui & $0(0)$ & $3(21,4)$ & $10(100)$ & $14(77,8)$ \\
\hline \multirow{3}{*}{ Dokumentasi BCG } & Positif & $3(100)$ & $10(71,4)$ & $10(100)$ & $10(55,6)$ \\
\hline & Negatif & $0(0)$ & $1(7,1)$ & $0(0)$ & $2(11,1)$ \\
\hline & Tidak diketahui & $0(0)$ & $3(21,4)$ & $0(0)$ & $6(33,3)$ \\
\hline \multirow[t]{3}{*}{ Kontak TB } & Positif & $0(0)$ & $0(0)$ & $0(0)$ & $5(27,8)$ \\
\hline & Negatif & $3(100)$ & $8(57,1)$ & $8(80)$ & $13(72,2)$ \\
\hline & Tidak diketahui & $0(0)$ & $6(42,9)$ & $2(20)$ & $0(0)$ \\
\hline \multirow[t]{4}{*}{ Etiologi } & Bakterial & $3(100)$ & $0(0)$ & $2(20)$ & $0(0)$ \\
\hline & TB & $0(0)$ & $14(100)$ & $0(0)$ & $18(100)$ \\
\hline & Viral & $0(0)$ & $0(0)$ & $7(70)$ & $0(0)$ \\
\hline & Autoimun & $0(0)$ & $0(0)$ & $1(10)$ & $0(0 \%)$ \\
\hline
\end{tabular}


Gilbert Sterling Octavius dkk: Infeksi susunan saraf pusat pada anak: sebuah studi potong lintang deskriptif selama lima tahun

Tabel 2. Data klinis saat masuk rumah sakit

\begin{tabular}{|c|c|c|c|c|c|}
\hline \multirow[t]{2}{*}{ Variabel } & & \multicolumn{2}{|c|}{ Meningitis } & \multirow[t]{2}{*}{ Ensefalitis (\%) } & \multirow[t]{2}{*}{ Meningoensefalitis (\%) } \\
\hline & & Bakterial (\%) & TB (\%) & & \\
\hline \multirow{3}{*}{$\begin{array}{l}\text { Derajat medical research council } \\
\text { (MRC) }\end{array}$} & MRC 1 & N/A & $4(28,6)$ & N/A & $4(22,2)$ \\
\hline & MRC 2 & & $8(57,1)$ & & $2(11,1)$ \\
\hline & MRC 3 & & $2(14,3)$ & & $12(66,7)$ \\
\hline \multirow{4}{*}{$\begin{array}{l}\text { Durasi gejala sebelum masuk } \\
\text { rumah sakit (hari) }\end{array}$} & $0-7$ & $2(66,7)$ & $7(50)$ & $10(100)$ & $16(88,9)$ \\
\hline & $8-14$ & $1(33,3)$ & $1(7,1)$ & $0(0)$ & $2(11,1)$ \\
\hline & $15-21$ & $0(0)$ & $2(14,3)$ & $0(0)$ & $0(0)$ \\
\hline & $>21$ & $0(0)$ & $3(21,4)$ & $0(0)$ & $0(0)$ \\
\hline \multirow[t]{7}{*}{ Gejala utama } & Penurunan kesadaran & $0(0)$ & $5(35,7)$ & $6(60)$ & $10(55,6)$ \\
\hline & Demam & $1(33,3)$ & $4(28,6)$ & $0(0)$ & $2(11,1)$ \\
\hline & Muntah & $0(0)$ & $0(0)$ & $0(0)$ & $0(0)$ \\
\hline & Kejang & $1(33,3)$ & $3(21,4)$ & $4(40)$ & $4(22,2)$ \\
\hline & Sesak & $0(0)$ & $0(0)$ & $0(0)$ & $1(5,6)$ \\
\hline & Kelemahan & $0(0)$ & $2(14,3)$ & $0(0)$ & $0(0)$ \\
\hline & Sakit kepala & $1(33,3)$ & $0(0)$ & $0(0)$ & $1(5,6)$ \\
\hline \multirow[t]{4}{*}{ Status nutrisi } & Berlebih & N/A & N/A & N/A & $4(22,2)$ \\
\hline & Baik & & & & $6(33,3)$ \\
\hline & Kurang & & & & $2(11,1)$ \\
\hline & Buruk & & & & $1(5,6)$ \\
\hline \multirow[t]{3}{*}{ Status berat badan } & Cukup & $2(66,7)$ & $5(35,7)$ & $9(90)$ & $3(16,7)$ \\
\hline & Kurang & $1(33,3)$ & $5(35,7)$ & $1(10)$ & $1(5,6)$ \\
\hline & Buruk & $0(0)$ & $4(28,6)$ & $0(0)$ & $0(0)$ \\
\hline \multirow[t]{4}{*}{ GCS } & 15 & $2(66,7)$ & $8(57,1)$ & $4(40)$ & $4(22,2)$ \\
\hline & $12-14$ & $0(0)$ & $2(14,3)$ & $3(30)$ & $0(0)$ \\
\hline & $9-11$ & $0(0)$ & $3(21,4 \%)$ & $1(10)$ & $9(50)$ \\
\hline & $\leq 8$ & $1(33,3)$ & $1(7,1)$ & $3(30)$ & $5(27,8)$ \\
\hline \multirow[t]{8}{*}{ Fungsi motoris } & Normal & $2(66,7)$ & $7(50)$ & $7(70)$ & $6(33,3)$ \\
\hline & Hemiparesis kanan & $0(0)$ & $0(0)$ & $1(10)$ & $2(11,1)$ \\
\hline & Hemiparesis kiri & $0(0)$ & $3(21,4)$ & $0(0)$ & $2(11,1)$ \\
\hline & Kuadriparesis & $0(0)$ & $0(0)$ & $0(0)$ & $1(5,6)$ \\
\hline & Monoparesis & $0(0)$ & $1(7,1)$ & $0(0)$ & $0(0)$ \\
\hline & Paraparesis & $0(0)$ & $1(7,1)$ & $0(0)$ & $1(5,6)$ \\
\hline & Klonus & $1(33,3)$ & $0(0)$ & $0(0)$ & $0(0)$ \\
\hline & Spastis & $0(0)$ & $2(14,3)$ & $2(20)$ & $6(33,3)$ \\
\hline \multirow[t]{2}{*}{ Iritasi meningens } & Ada & $2(66,7)$ & $8(57,1)$ & N/A & $14(77,8)$ \\
\hline & Tidak & $1(33,3)$ & $6(42,9)$ & & $4(22,2)$ \\
\hline \multirow[t]{2}{*}{ Peningkatan tekanan intrakranial } & Ada & $0(0)$ & $5(35,7)$ & $1(10)$ & $9(50)$ \\
\hline & Tidak & $3(100)$ & $9(64,3)$ & $9(90)$ & $9(50)$ \\
\hline \multirow[t]{2}{*}{ Disfungsi Batang otak } & Ada & $0(0)$ & $3(21,5)$ & $0(0)$ & $3(16,7)$ \\
\hline & Tidak & $3(100)$ & $11(78,5)$ & $3(100)$ & $15(83,3)$ \\
\hline \multirow[t]{2}{*}{ Paresis nervus kranialis } & Ada & $0(0)$ & $3(21,5)$ & $1(10)$ & $7(38,9)$ \\
\hline & Tidak & $3(100)$ & $11(78,5)$ & $9(90)$ & $11(61,1)$ \\
\hline Durasi rawat inap & Median (hari) & 8 hari & 12 hari & 11 hari & 15,5 hari \\
\hline \multirow[t]{2}{*}{ Keadaan pulang dari rumah sakit } & Hidup & $3(100)$ & $13(92,9)$ & $9(90)$ & $13(72,2)$ \\
\hline & Meninggal & $0(0)$ & $1(7,1)$ & $1(10)$ & $5(27,8)$ \\
\hline \multirow[t]{2}{*}{ Perawatan } & Bangsal & $3(100)$ & $9(64,3)$ & $7(70)$ & $13(72,2)$ \\
\hline & ICU & $0(0)$ & $5(35,7)$ & $3(30)$ & $5(27,8)$ \\
\hline
\end{tabular}


sampel tertera pada Tabel 1. Kejadian infeksi pada anak didominasi oleh anak berjenis kelamin laki-laki. Data demografi juga menunjukkan bahwa penyebab terbesar kejadian infeksi susunan saraf pusat adalah TB diikuti oleh infeksi bakterial dan autoimun.

Pasien dengan diagnosis meningoensefalitis sebagian besar dikategorikan pada derajat MRC 3, sedangkan MTB datang dengan derajat MRC 2 (Tabel 2). Durasi gejala yang dialami sebagian besar pasien pada 0-7 hari sebelum masuk rumah sakit dengan gejala utama penurunan kesadaran, demam, dan kejang. Pasien dengan meningoensefalitis datang dengan penurunan kesadaran (GCS) yang lebih parah dengan tanda iritasi menigens dengan frekuensi yang lebih sering dibandingkan dengan meningitis dan ensefalitis. Sebagian besar pasien infeksi susunan saraf pusat tidak mengalami disfungsi motoris kecuali pada pasien MTB (50\%) dan meningoensefalitis (67,7\%). Pasien meningoensefalitis mengalami peningkatan tekanan intrakranial sebanyak $50 \%$ dan disfungsi batang otak $16,7 \%$. Disfungsi batang otak juga terjadi pada pasien MTB sebesar 21,5\%. Penyebab mortalitas yang tertinggi pada pasien infeksi susunan saraf pusat berdasarkan data yang dikumpulkan menunjukkan meningoensefalitis memiliki tingkat mortalitas yang tertinggi, yaitu 27,8\%.

Hasil pemindaian CT tidak menunjukkan adanya tanda basal meningitis pada semua pasien (Tabel 3). Tuberkuloma terjadi pada $7(38,9 \%)$ pasien anak dengan meningoensefalitis, sedangkan infark hanya terdapat pada $1(33,3 \%)$ pasien anak dengan meningitis bakteri, $6(42,9 \%)$ pada pasien anak meningitis TB, dan $5(27,8 \%)$ pasien anak dengan meningoensefalitis.

Tabel 3. Data diagnostik pada saat masuk rumah sakit

\begin{tabular}{|c|c|c|c|c|c|}
\hline Variabel CT scan & & \multicolumn{2}{|c|}{ Meningitis } & Ensefalitis (\%) & Meningoensefalitis (\%) \\
\hline \multirow[t]{2}{*}{ Basal meningitis } & Ada & $0(0)$ & $0(0)$ & $0(0)$ & $0(0)$ \\
\hline & Tidak & $3(100)$ & $13(92,9)$ & $0(0)$ & $18(100)$ \\
\hline \multirow[t]{2}{*}{ Tuberkuloma } & Ada & $0(0)$ & $1(7,1)$ & $0(0)$ & $7(38,9)$ \\
\hline & Tidak & $3(100)$ & $12(85,7)$ & $0(0)$ & $11(61,1)$ \\
\hline \multirow[t]{2}{*}{ Infark } & Ada & $1(33,3)$ & $6(42,9)$ & $0(0)$ & $5(27,8)$ \\
\hline & Tidak & $2(66,7)$ & $7(50)$ & $0(0)$ & $13(72,2)$ \\
\hline \multirow[t]{3}{*}{ Hidrosefalus } & Communicating & $0(0)$ & $6(42,9)$ & $0(0)$ & $9(50)$ \\
\hline & Non-Communicating & $0(0)$ & $1(7,1)$ & $0(0)$ & $1(5,6)$ \\
\hline & Tidak ada & $3(100)$ & $6(42,9)$ & $0(0)$ & $8(44,4)$ \\
\hline \multirow[t]{2}{*}{ Abses } & Ada & $0(0)$ & $0(0)$ & $0(0)$ & $5(27,8)$ \\
\hline & Tidak & $3(100)$ & $13(92,9)$ & $0(0)$ & $13(72,2)$ \\
\hline \multirow[t]{2}{*}{ Empiema } & Ada & $1(33,3)$ & $0(0)$ & $0(0)$ & $0(0)$ \\
\hline & Tidak & $2(66,7)$ & $13(92,9)$ & $0(0)$ & $18(100)$ \\
\hline \multirow[t]{2}{*}{ Edema } & Ada & $0(0)$ & $2(14,3)$ & $1(10)$ & $7(38,9)$ \\
\hline & Tidak & $3(100)$ & $11(78,6)$ & $0(0)$ & $11(61,1)$ \\
\hline Lainnya & Jumlah & $0(0)$ & $0(0)$ & $2(20)$ & $0(0)$ \\
\hline Normal & Jumlah & $1(33,3)$ & $0(0)$ & $2(20)$ & $0(0)$ \\
\hline Tidak dilakukan & Jumlah & $0(0)$ & $1(7,1)$ & $5(50)$ & $0(0)$ \\
\hline \multirow[t]{5}{*}{ Foto Rontgen dada } & TB milier & $0(0)$ & $1(7,1)$ & $0(0)$ & $1(5,6)$ \\
\hline & Infiltrat & $0(0)$ & $3(21,4)$ & $2(20)$ & $8(44,4)$ \\
\hline & Abnormalitas lainnya & $0(0)$ & $2(14,3)$ & $0(0)$ & $1(5,6)$ \\
\hline & Normal & $0(0)$ & $3(21,4)$ & $2(20)$ & $2(11,1)$ \\
\hline & Tidak dilakukan & $3(100)$ & $5(35,7)$ & $6(60)$ & $6(33,3)$ \\
\hline \multirow[t]{4}{*}{ Kultur } & Positif dari LCS & $1(33,3)$ & $0(0)$ & $2(20)$ & $0(0)$ \\
\hline & Positif dari sampel lain & $0(0)$ & $1(7,1)$ & $3(30)$ & $1(5,6)$ \\
\hline & Negatif & $0(0)$ & $9(64,3)$ & $4(40)$ & $9(50)$ \\
\hline & Tidak diuji & $2(66,7)$ & $4(28,6)$ & $1(10)$ & $8(44,4)$ \\
\hline
\end{tabular}


Gilbert Sterling Octavius dkk: Infeksi susunan saraf pusat pada anak: sebuah studi potong lintang deskriptif selama lima tahun

Tabel 4. Temuan LCS pada saat masuk rumah sakit

\begin{tabular}{|c|c|c|c|c|c|}
\hline \multirow[t]{2}{*}{ Variabel } & & \multicolumn{2}{|c|}{ Meningitis } & \multirow[t]{2}{*}{ Ensefalitis (\%) } & \multirow[t]{2}{*}{ Meningoensefalitis (\%) } \\
\hline & & Bakterial (\%) & TB (\%) & & \\
\hline \multirow[t]{5}{*}{ Limfosit } & Median $(\operatorname{sel} / \mu \mathrm{l})$ & N/A & 95 & 12,5 & $3-167$ \\
\hline & Range $(\mathrm{sel} / \mu \mathrm{l})$ & & $5-657$ & $1-791$ & 31 \\
\hline & Normal: $0-10 \mathrm{sel} / \mu \mathrm{l}$ & $1(33,3)$ & $3(20)$ & $2(20)$ & $3(16,7)$ \\
\hline & Abnormal: > $10 \mathrm{sel} / \mu \mathrm{l}$ & $0(0)$ & $9(60)$ & $2(20)$ & $6(33,3)$ \\
\hline & Tidak ada data & $2(66,7)$ & $3(20)$ & $6(60)$ & $9(50)$ \\
\hline \multirow[t]{2}{*}{ PMN } & Median $(\operatorname{sel} / \mu \mathrm{l})$ & N/A & 11 & 1,5 & 32,5 \\
\hline & Range $(\mathrm{sel} / \mu \mathrm{l})$ & & $1-126$ & $0-174$ & $0-39$ \\
\hline \multirow[t]{5}{*}{ Protein } & Median $(g / L)$ & N/A & 0,8 & 0,54 & 0,86 \\
\hline & Range (g/L) & & $0,24-7,76$ & $0,12-3,97$ & $0,21-14,07$ \\
\hline & Normal: $\leq 0,8 \mathrm{~g} / \mathrm{L}$ & $1(33,3)$ & $4(26,7)$ & $2(20)$ & $3(16,7)$ \\
\hline & Abnormal: > 0,8 g/L & $0(0)$ & $8(53,3)$ & $2(20)$ & $6(33,3)$ \\
\hline & No Data & $2(66,7)$ & $3(20)$ & $6(60)$ & $9(50)$ \\
\hline Serum & $\operatorname{Median}(\mathrm{mg} / \mathrm{dl})$ & 92 & 125,5 & 109,5 & 99 \\
\hline \multirow[t]{4}{*}{ Glukosa } & Range (mg/dl) & $80-105$ & $83-130$ & $5-197$ & $82-272$ \\
\hline & Normal: $60-140 \mathrm{mg} / \mathrm{dl}$ & $3(100)$ & $10(66,7)$ & $5(50)$ & $11(78,6)$ \\
\hline & $\begin{array}{l}\text { Abnormal: }<60 \mathrm{mg} / \mathrm{dl} \\
\text { atau }>140 \mathrm{mg} / \mathrm{dl}\end{array}$ & $0(0)$ & $0(0)$ & $5(50)$ & $2(14,3)$ \\
\hline & No Data & $0(0)$ & $5(27,7)$ & $0(0)$ & $1(5,6)$ \\
\hline \multirow[t]{3}{*}{ Glukosa LCS } & Median (mg/dl) & N/A & 46 & 19,5 & 52 \\
\hline & Range (mg/dl) & & $10,9-140$ & $5-107$ & $22-81$ \\
\hline & No Data & $3(100)$ & $3(20)$ & $6(60)$ & $9(50)$ \\
\hline Rasio glukosa & Median (\%) & N/A & 45 & 60 & 48 \\
\hline \multirow[t]{4}{*}{ LCS/serum } & Range (\%) & & $22-139$ & $33-106$ & $22-86$ \\
\hline & Normal $(60-80 \%)$ & & $0(0)$ & $1(10)$ & $2(11,1)$ \\
\hline & $\begin{array}{l}\text { Abnormal }(<60 \% \text { atau } \\
>80 \%)\end{array}$ & & $10(66,7)$ & $3(30)$ & $6(33,3)$ \\
\hline & No Data & $3(100)$ & $5(33,3)$ & $6(60)$ & $10(55,6)$ \\
\hline \multirow[t]{3}{*}{ Tes Noone } & Positif & $0(0)$ & $10(66,7)$ & $0(0)$ & $4(22,2)$ \\
\hline & Negatif & $0(0)$ & $2(13,3)$ & $0(0)$ & $5(27,8)$ \\
\hline & No Data & $3(100)$ & $3(20)$ & $10(100)$ & $9(50)$ \\
\hline \multirow[t]{3}{*}{ Tes Pandy } & Positif & $0(0)$ & $10(66,7)$ & $0(0)$ & $4(22,2)$ \\
\hline & Negatif & $0(0)$ & $2(13,3)$ & $0(0)$ & $5(27,8)$ \\
\hline & No Data & $3(100)$ & $3(20)$ & $10(100)$ & $9(50)$ \\
\hline
\end{tabular}

Pada pasien meningoensefalitis, 55,6\% mengalami hidrosefalus dibanding $50 \%$ pasien meningitis TB. Hasil kultur LCS menunjukkan sensitifitas yang rendah, semua pemeriksaan kultur LCS pada pasien meningitis TB dan meningoensefalitis tidak ditemukannya etiologi dari masing-masing penyakit. Pada pemeriksaan LCS, 9 pasien MTB (60\%) menunjukkan jumlah limfosit yang abnormal dengan rentang $5-657 \mathrm{sel} / \mu \mathrm{l}$ (Tabel 4). Delapan pasien MTB (53,3\%) menunjukkan kadar protein yang abnormal dan 10 pasien dengan hasil Nonne-Pandy positif. Tidak ada penemuan yang spesifik pada pasien meningitis bakterial, ensefalitis, dan meningoensefalitis.

Tigabelas $13(72,2 \%)$ pasien meningoensefalitis menjalani pengobatan dengan obat anti TB dan 13 $(92,9 \%)$ pasien meningitis menjalani pengobatan obat anti TB. Penanganan hidrosefalus dilakukan pada 5 pasien meningitis tuberkulosis, $1(7,1 \%)$ diberikan diuretik dan $4(28,6 \%)$ dilakukan pemasangan shunt. Untuk pasien meningoensefalitis, tatalaksana diuretik 
Gilbert Sterling Octavius dkk: Infeksi susunan saraf pusat pada anak: sebuah studi potong lintang deskriptif selama lima tahun

Tabel 5. Pengobatan yang diberikan selama di rumah sakit

\begin{tabular}{llcccc}
\hline Variabel & & \multicolumn{2}{c}{ Meningitis } & Ensefalitis (\%) & Meningoensefalitis (\%) \\
\cline { 2 - 3 } & \multicolumn{2}{c}{ Bakterial (\%) } & TB (\%) & & \\
\hline \multirow{2}{*}{ Pengunaan obat anti TB } & Ya & $0(0)$ & $13(92,9)$ & $0(0)$ & $13(72,2)$ \\
& Tidak & $3(100)$ & $1(7,1)$ & $10(100)$ & $5(27,8)$ \\
Pengobatan hidrosefalus & Diuretik & $0(0)$ & $1(7,1)$ & $0(0)$ & $2(11,1)$ \\
& Shunt & $0(0)$ & $4(28,6)$ & $0(0)$ & $3(16,7)$ \\
& Tidak ada & $3(100)$ & $9(64,3)$ & $10(100)$ & $13(72,2)$ \\
\multirow{5}{*}{ Kortikosteroid } & pengobatan & & & & \\
\multirow{2}{*}{ Mannitol } & Ya & $2(66,7)$ & $11(78,6)$ & $5(50)$ & $15(83,3)$ \\
& Tidak & $1(33,3)$ & $3(21,4)$ & $5(50)$ & $3(16,7)$ \\
& Ya & $0(0)$ & $0(0)$ & $1(10)$ & $2(11,1)$ \\
& Tidak & $3(100)$ & $14(100)$ & $9(90)$ & $16(88,9)$ \\
\hline
\end{tabular}

untuk hidrosefalus diberikan pada $2(11,1 \%)$ pasien dan shunt dilakukan pada $3(16,7 \%)$ pasien.

\section{Pembahasan}

Sesuai dengan data dari Infodatin TB tahun 2018, hasil penelitian menunjukkan mayoritas infeksi susunan saraf pusat terjadi pada anak dengan jenis kelamin laki-laki. Satu penelitian juga menunjukkan mayoritas pasien ensefalitis adalah laki-laki. ${ }^{2}$ Infeksi HIV dapat menjadi faktor risiko, meningkatkan mortalitas, memperburuk prognosis, dan memengaruhi keberhasilan terapi pada infeksi SSP. ${ }^{21,22}$

Prevalensi pasien yang tidak mengetahui status imunisasi BCG masih cukup tinggi, yaitu 21,4\% pada pasien meningitis TB dan 33,3\% pada pasien meningoensefalitis. Hal ini dapat terjadi akibat tingkat pendidikan keluarga pasien rendah dan kepedulian masyarakat kurang terhadap pentingnya pemberian imunisasi, khususnya BCG pada anak usia 0-2 bulan. Dalam salah satu penelitian menunjukkan bahwa imunisasi BCG dapat membantu mengurangi angka kejadian, mortalitas dari meningitis TB. ${ }^{23}$

Berdasarkan usia saat masuk rumah sakit, jumlah pasien meningitis TB di bawah 5 tahun lebih banyak, mencapai $57,1 \%$, sesuai dengan literatur yang ada. ${ }^{24}$ Usia mayoritas pasien dengan ensefalitis adalah di bawah 2 tahun. Terdapat literatur yang menyatakan bahwa pasien dengan ensefalitis viral rata-rata terjadi pada usia 29 bulan. $^{2}$

Awitan gejala meningitis TB pada anak cenderung beragam sesuai dengan hasil penelitian. Mayoritas memiliki awitan sub-akut, hal ini disebabkan oleh gejala awal yang sering menyerupai penyakit lain sehingga mempersulit diagnosis. Rata-rata pasien meningitis TB mengalami gejala 10 hari sebelum diagnosis dengan rentang waktu yang sangat luas (1 hari hingga 9 bulan). ${ }^{16}$ Seluruh pasien meningoensefalitis disebabkan oleh bakteri TB. Hal ini bertentangan dengan penelitian oleh Khajeh $\mathrm{dkk}^{25}$ yang menyatakan bahwa mayoritas pasien meningoensefalitis disebabkan oleh bakteri atau virus.

Gejala yang muncul pada pasien meningitis TB cenderung bervariasi, sesuai dengan teori yang ada. Namun, sebagian besar pasien infeksi SSP memiliki status nutrisi baik dan status berat badan cukup, meskipun hasil penelitian tidak dapat menunjukkan pasien yang mengalami penurunan berat badan atau berat badan yang tidak naik. Kontak TB sebagian besar menunjukkan hasil negatif dan tidak diketahui.

Hanya $42 \%$ pasien meningitis TB yang memiliki abnormalitas pada Rontgen dada. Berdasarkan Juknis 2016, abnormalitas pada Rontgen dada memang tidak selalu ditemukan pada pasien dengan meningitis $\mathrm{TB}$, dengan $20-50 \%$ kasus meningitis TB memiliki foto dada normal. Temuan seperti kultur pada penelitian mayoritas menunjukkan hasil negatif sesuai dengan data dari di Indonesia yang menyatakan bahwa sensitivitas kultur pada meningitis TB yang hanya mencapai 50$70 \% .^{17}$

Hasil pemeriksaan LCS pada meningitis TB menggambarkan bahwa mayoritas pasien memiliki limfositosis, peningkatan kadar protein, dan penurunan kadar glukosa LCS/serum, sugestif meningitis TB. ${ }^{17}$ Pada penelitian ini, pasien meningoensefalitis memiliki gambaran LCS cukup bervariasi, dengan mayoritas 
mengarah pada etiologi TB. Sementara pada pasien dengan ensefalitis menurut Meligy $\mathrm{dkk},{ }^{2}$ terdapat pleiositosis limfositik, meskipun pada 48 jam pertama awitan penyakit sering terdapat hasil predominan neutrofil. Hasil penelitian pada pasien ensefalitis kurang menggambarkan hal ini dikarenakan banyak pasien yang tidak memiliki data pemeriksaan LCS.

Pada penelitian ini, meningitis TB hasil CT scan yang paling banyak ditemukan adalah adanya gambaran hidrosefalus komunikans dan infark. Hanya sedikit yang mengalami edema dan tuberkuloma. Temuan ini cukup sesuai dengan penelitian yang dilakukan di Afrika Selatan. ${ }^{24}$ Pada pasien dengan ensefalitis, gambaran radiologi yang terlihat adalah normal atau dapat ditemukan edema, sesuai dengan penelitian oleh Meligy $\mathrm{dkk}^{2}$ yang menyatakan bahwa gambaran CT mayoritas adalah normal, kadang dapat terlihat edema atau hipodens akibat hipoksia. ${ }^{2}$

Prognosis pasien meningitis TB yang mengalami disabilitas cukup tinggi, mencapai $21,5 \%$, dengan disabilitas yang paling banyak dialami adalah disfungsi saraf kranial, disfungsi batang otak, dan hemiparesis sinistra, Hal ini dapat terjadi didukung dengan temuan pemeriksaan radiologis yang ditemui adalah gambaran infark dan hidrosefalus komunikans. Penelitian oleh van Well $\mathrm{dkk}^{24}$ menunjukkan bahwa $84 \%$ pasien dengan meningitis TB mengalami sekuela ringan hingga berat, dengan 63\% mengalami gangguan fungsi motorik, 38\% mengalami disfungsi batang otak, dan $26 \%$ mengalami palsi nervus kranial.

Tingkat mortalitas meningitis TB 7,1\% cukup tinggi meskipun sudah diberikan terapi sesuai dengan etiologi. Angka ini lebih kecil jika dibandingkan dengan rata-rata mortalitas yang terdata di Indonesia. Lebih dari $90 \%$ pasien mengalami perbaikan setelah terapi. ${ }^{17}$

Pada pasien dengan ensefalitis, $90 \%$ mengalami peningkatan tekanan intrakranial. Tingkat disabilitas cukup tinggi, dengan $10 \%$ mengalami hemiparesis, $20 \%$ mengalami spastik, 10\% mengalami paresis nervus kranialis. Tingkat mortalitasnya adalah 10\%. Hasil ini masih lebih rendah dibanding dengan penelitian Meligy $\mathrm{dkk}^{2}$ dengan tingkat mortalitas $22 \%$, meskipun pasien dengan defisit fokal hanya $7 \%$.

Pasien dengan meningoensefalitis memiliki tingkat mortalitas $27,8 \%$, hasil ini jauh lebih tinggi dari hasil penelitian oleh Khajeh $\mathrm{dkk}^{25}$ yang hanya 7,2\%. Faktor yang memengaruhi peningkatan tingkat mortalitas ini dapat diakibatkan oleh obat anti TB (OAT) diberikan pada sebagian besar pasien meningoensefalitis karena etiologi dari meningoensefalitis mengarah pada bakteri TB berdasarkan hasil pemeriksaan LCS.

Kortikosteroid diberikan kepada sebagian besar pasien dengan infeksi SSP. Kortikosteroid diberikan pada pasien dengan meningitis TB karena kortikosteroid dapat menurunkan mortalitas, tetapi tidak terlalu berpengaruh pada sekuela meningitis TB. ${ }^{24}$ Pada meningitis bakteri tidak terlihat perbedaan signifikan pada angka mortalitas pada pasien yang diberikan kortikosteroid, tetapi mengurangi terjadinya sekuela. ${ }^{26}$ Data juga kurang mendukung penggunaan kortikosteroid pada ensefalitis viral. ${ }^{27}$

Mannitol tidak digunakan pada mayoritas pasien dengan infeksi SSP yang mengalami peningkatan tekanan intrakranial. Penelitian Tasker ${ }^{28}$ menyatakan bahwa terapi menggunakan mannitol kurang memiliki manfaat terhadap penurunan ICP, dan pada beberapa kasus dapat memperburuk keadaan pasien.

\section{Kesimpulan}

Infeksi SSP lebih sering terjadi pada anak di bawah $<5$ tahun walaupun meningoensefalitis lebih sering terjadi pada anak usia $>5$ tahun. Sebagian besar anak datang dengan awitan gejala akut, penurunan kesadaran merupakan presentasi utama. Tuberkulosis masih merupakan penyebab utama dari infeksi SSP sehingga kontak TB, status imunisasi BCG, dan tes Mantoux wajib ditanyakan dan dilakukan. Pasien dengan meningitis $\mathrm{TB}$ atau meningoensefalitis $\mathrm{TB}$ datang dengan derajat MRC 2-3 yang berkorelasi dengan morbiditas dan mortalitas tinggi sehingga diagnosis dan tatalaksana yang tepat diperlukan oleh para klinisi untuk memperbaiki luaran pasien.

\section{Daftar pustaka}

1. Shrestha R, Tandukar S, Ansari S, dkk. Bacterial meningitis in children under 15 years of age in Nepal. BMC Pediatr 2015;15:1-7.

2. Meligy B, Kadry D, Draz I, Marzouk H, El Baroudy N, El Rifay A. Epidemiological profile of acute viral encephalitis in a sample of Egyptian Children. Open Access Maced J of Med Sci 2018;6:423-9.

3. Kenfak A, Eperon G, Schibler M, Lamoth F, Vargas M, Stahl J. Diagnostic approach to encephalitis and meningoencephalitis in adult returning travellers. Clin Microbiol Infect 2019;25:415-21. 
Gilbert Sterling Octavius dkk: Infeksi susunan saraf pusat pada anak: sebuah studi potong lintang deskriptif selama lima tahun

4. Sharifi-Mood B, Khajeh A, Metanat M, Rasouli A. Epidemiology of Meningitis Studied at a University Hospital in Zahedan, South-Eastern Iran. Int J Infect 2015;2:1-3.

5. Tegene B, Gebreselassie S, Fikrie N. Bacterial meningitis: a fiveyear retrospective study among patients who had attended at University of Gondar Teaching Hospital, Northwest Ethiopia. Biomed Res Ther 2015;2:270-8.

6. Marji S. Baccterial meningitis in children. Rawal Med J 2007;32:109-11.

7. Durand ML, Calderwood SB, Weber DJ, dkk. Acute bacterial meningitis in adults: A review of 493 episodes. N Engl J Med 1993;328:21-8.

8. Grenon SL, Salvi Grabulosa MC, Regueira MM, Fossati MS, von Specht MH. Pneumococcal meningitis in children under 15 years of age in Misiones (Argentina). Sixteen year's epidemiological surveillance. Rev Argent Microbiol 2014;46:14-23.

9. Tan L, Qui P, Ha D, dkk. Viral etiology of encephalitis in children in Southern Vietnam: results of a one-year prospective descriptive study. PLoS Negl Trop Dis 2010;4:e854:1-10.

10. Tack DM, Holman RC, Folkema AM, Mehal JM, Blanton JD, Sejvar JJ. Trends in encephalitis-associated deaths in the United States, 1999-2008. Neuroepidemiology 2014;43: 1-8.

11. Beig FK, Malik A, Rizvi M, Acharya D, Khare S. Etiology and clinico-epidemiological profile of acute viral encephalitis in children of western Uttar Pradesh, India. Int J Infect Dis 2010;14:141-6.

12. Glaser CA, Honarmand S, Anderson LJ, dkk. Beyond viruses: clinical profiles and etiologies associated with encephalitis. Clin Infect Dis 2006;43:1565-77.

13. Srey VH, Sadones H, Ong S, dkk. Etiology of encephalitis syndrome among hospitalized children and adults in Takeo, Cambodia, 1999-2000. Am J Trop Med Hyg 2002;66:200-7.

14. Solomon T, Dung NM, Kneen R, dkk. Seizures and raised intracranial pressure in Vietnamese patients with Japanese encephalitis. Brain 2002;125:1084-93.

15. Venkatesan A, Tunkel AR, Bloch KCdkk. Case definitions, diagnostic algorithms, and priorities in encephalitis: consensus statement of the international encephalitis consortium. Clin
Infect Dis 2013;57:1114-28.

16. Marx G, Chan E. Tuberculous meningitis: diagnosis and treatment overview. Tuberculosis Res Treat 2011;2011:1-9.

17. Kementrian Kesehatan Republik Indonesia. Petunjuk teknis manajemen dan tatalaksana TB anak. Jakarta: Kemkes RI; 2016.h1-84.

18. Mucaj S, Dreshaj S, Kabashi S, dkk. Tuberculous meningoencephalitis. Med Arh 2010;64: 89-90.

19. British Medical Research Council. Streptomycin treatment of tuberculous meningitis. Br Med J 1948;1:582-97.

20. World Heath Organization. Treatment of tuberculosis; guidance for national tuberculosis programmes on the management of tuberculosis in children. Geneva, Switzerland: World Heath Organization; 2006. Diakses pada 12 Desember 2019 Didapat dari: whqlibdoc.who.int/ hq/2006/WHO_HTM_ TB_2006.371_eng.pdf..

21. Molyneux EM, Tembo M, Kayira K, dkk. The effect of HIV infection on paediatric bacterial meningitis in Blantyre, Malawi. Arch Dis Child 2004;88:1112-8.

22. Vinnard C, Macgregor RR. Tuberculous meningitis in HIVinfected individuals. Curr HIV/AIDS Rep 2009;6:139-45.

23. Trunz BB, Fine P, Dye C. Eff ect of BCG vaccination on childhood tuberculous meningitis and miliary tuberculosis worldwide: a metaanalysis and assessment of cost-eff ectiveness. Lancet 2006;367:1173-80.

24. Well GTJ van, Paes BF, Terwee CB, dkk. Twenty years of pediatric tuberculous meningitis: a retrospective cohort study in Western Cape of South Africa. Pediatrics 2009;123:e1-8.

25. Khajeh A, Sharifi-Mood B, Soleimani G R. Pediatric meningoencephalitis; a research on patients hospitalized in Zahedan, Southeastern Iran, Int J Infect 2015; 2:e23835.

26. Mongelluzzo J, Mohamad Z, Have TR Ten. Corticosteroids and Mortality in Children With Bacterial meningitis. JAMA 2008;299-304.

27. Esposito S, Picciolli I, Semino M, Principi N. Steroids and childhood encephalitis. Pediatr Infect Dis J 2012;21:759-60.

28. Tasker RC. Raised intracranial pressure during central nervous system infection: what should we do about it? Crit Care Med 2014;42:1936-8. 